\title{
Relationship Of Gallstone Types And Bile Microorganism Infection In Gallstone Patients In H. Adam Malik Hospital And Network Hospital
}

\author{
${ }^{*}$ Department of Surgery, Faculty of Medicine, Universitas Sumatera Utara \\ DOI: 10.29322/IJSRP.11.12.2021.p12039 \\ http://dx.doi.org/10.29322/IJSRP.11.12.2021.p12039
}

Rizki Fadhil Nasution*, Asrul*, Adi Muradi Muhar*, Putri Chairani Eyanoer*

\begin{abstract}
Introduction: The prevalence of gallstones varies between the population in each country and the ethnicity of the country. Incidence is reported in $11-36 \%$ of the world's population, $10 \%$ in the population of Western countries. In developing countries the prevalence varies from $15-25 \%$. Research on the analysis of the bile acid composition of the microbiota shows the role of bacteria in the formation of pigment stones. From several patients after cholecystectomy, infection and sepsis occurred, the patient's bile culture - bacteria were found. Methods: To analyze the type of gallstones macroscopically with culture to see the presence or absence of infection with microorganisms in bile. patients with cholelithiasis or gallstones at HAM Hospital and Network Hospital. Results: In this study several results were found, namely stones occur mostly at the age
\end{abstract}

\section{INTRODUCTION}

$\mathrm{T}$ he prevalence of gallstones varies between the population in each country and the ethnicity of the country (Nurman, 2007; Zamil, Abbas and Yaqoob, 2021). Incidence is reported in 11-36\% of the world's population, $10 \%$ in the population of Western countries (Cariati, 2014). In developing countries the prevalence varies from 15-25\%, in India 5-10\% (Singh et al., 2019), incidence in Taipei 5.3\%, in Japan 3.2\%, 10.7\% in China, $5.0 \%$ in Taiwan (Wang et al., 2018). In Asian countries the prevalence varies from $3 \%-10 \%$ (Chang et al., 2013). Meanwhile in Indonesia, incident reports have not been obtained and research has received less attention. Predictions of the incidence of gallstones and ducts are thought to be not much different from other countries in Southeast Asia (Sjamsuhidajat and Jong, 2016).

In healthy individuals, it is stated that bile in the gallbladder is sterile based on microbiological tests (Bistgani and Imani, 2013; Han et al., 2021). With the discovery of microorganisms from bile culture of gallstone patients, it is suspected that the occurrence of pigment gallstones is closely related to the role of bacteria (Matyjas et al., 2017; Zamil, Abbas and Yaqoob, 2021). Research has shown that the presence of microorganisms in bile and gallstones has a role in the formation of pigment stones. From the results of $75 \%$ pigment stone culture found the presence of bacteria. The characteristics of the bacteria determine the mechanism of gallstone formation (Stewart et al., 2006). From the same patient found the same type of bacteria both from stone culture and bile fluid (Matyjas et al. , 2017). Another investigator found the same bacteria in the bile and duodenum of the same choledocholithiasis patient (Han et al., 2021), of over 40 years, occur more in women, cholesterol stones are the most stones, on examination of bacteria more are negative, in samples with germs found Klebsiella pneumoniae the most and Enterococcus faecalis the least, the number of cholesterol and pigment stones is the same in proportion for the age group under 40 years. it was found that there was a relationship $(p<0.05)$ between the type of stone and the lab results. Conclusion: In this study, female patients generally had positive stones and males were more dominantly negative, and the type of stone had a relationship with the microorganism lab results.

Index Terms- gallstone types, bile microorganisms, infections, network hospitals

Research on the analysis of the bile acid composition of the microbiota shows the role of bacteria in the formation of pigment stones (Petrov et al., 2018). From several patients after cholecystectomy, infection and sepsis occurred, the patient's bile culture - bacteria were found (Bistgani and Imani, 2013). Various studies have tried to find a relationship between the type of stone and the presence of gallbladder infection. In Manado and North Sumatra, the type of gallbladder stone was assessed by gross infection (macroscopic) based on color and shape and then the relationship with infection was assessed histopathologically from the gallbladder mucosal wall (Kereh et al., 2015; Muhar, Siregar and Prabisma, 2021).

Based on the above background with different techniques and methods from researchers to see the relationship between risk factors for gallstones and gallbladder infection. So the researchers wanted to analyze the type of gallstones macroscopically with culture to see the presence or absence of infection with microorganisms in bile. patients with cholelithiasis or gallstones at HAM Hospital and Network Hospital.

\section{METHODS}

This research is observational analytic research with the design used in this research is Cross Sectional. The data taken is secondary data. This research is analytical because it aims to obtain the relationship between the type of stone and the type of microorganism as well as the pattern of bile fluid microorganisms in gallstone patients at $\mathrm{H}$. Adam Malik Hospital and Jejaring Hospital in Medan City 2019.

The research data were taken from patients receiving treatment from 2019 to February 2020 at H. Adam Malik Hospital 
and a network hospital in Medan City, Digestive Surgery Division. The sample of this study is part of the population who underwent cholecystectomy in $2019,2020,2021$. This study took samples by non-probability sampling, namely the consecutive sampling technique, in which all patients who met the inclusion and exclusion criteria were taken sequentially until the minimum sample size was met.

The inclusion criteria of the study were digestive surgery patients who were diagnosed with gallstones based on ultrasound investigations, aged $>18$ years and treated with cholecystectomy, patients had information on gallstone results established by ultrasound and patients had bile culture results written in the medical record. This research was carried out after obtaining ethical clearance from the Research Ethics Committee of the Faculty of Medicine, North Sumatra.

The study was conducted by collecting medical records of gallstone patients with cholecystectomy, collecting patient identities and operating reports (age, gender), collecting stone analysis and culture results, classifying stone types and culture results and analyzing and processing data. The statistical test used is chi-square. The significant test between the observed data and the expected data was carried out with a significance limit of $p$ $<0.05$. If the chi-square test does not meet the parametric requirements of the expected count value, then Fisher's exact test is performed.

\section{RESULTS}

This observational analytical study with a cross sectional design took secondary data which aimed to obtain the relationship between the type of stone and the type of microorganism and the pattern of the bile fluid microorganisms of gallstone patients at $\mathrm{H}$. Adam Malik Hospital and Network Hospital in Medan City 2019.

Table 1. Frequency Distribution of Stone Types by Age Category

\begin{tabular}{ccc}
\hline Stone types & \multicolumn{2}{c}{ Age } \\
\cline { 2 - 3 } & $<40$ years (\%) & $\geq 40$ years (\%) \\
\hline Cholesterol stones & $2(6,7 \%)$ & $9(30,0 \%)$ \\
Pigment stones & $2(6,7 \%)$ & $8(26,7 \%)$ \\
Mixed stones & 0 & $9(30,0 \%)$ \\
\hline Total & 4 & 26 \\
\hline
\end{tabular}

Based on table 1 above, it can be seen from this study that all patients under 40 years of age had the same number of Pigment and Cholesterol stones ( 2 patients; $6.7 \%$ ), where at the age above 40 the highest number of cholesterol stones and mixed types of stones ( 9 patients; $30.00 \%$ ).

Table 2. Frequency Distribution of Stone Types by Gender Stone types Gender

\begin{tabular}{lll}
\cline { 2 - 3 } & Male (\%) & Female (\%) \\
\hline Cholesterol stones & $5(16,7 \%)$ & $6(20,0 \%)$ \\
Pigment stones & $3(10,0 \%)$ & $7(23,5 \%)$ \\
Mixed stones & $4(13,3 \%)$ & $5(16,7 \%)$ \\
\hline Total & 12 & 18
\end{tabular}

Based on table 2 above, it can be seen that in the male sex the most cases of cholesterol stones (5 patients; $16.7 \%$ ) and in the female sex the most cases of pigment stones (7 patients; $23.5 \%$ ).

Table 3. Correlation between Stone Type and Lab Results

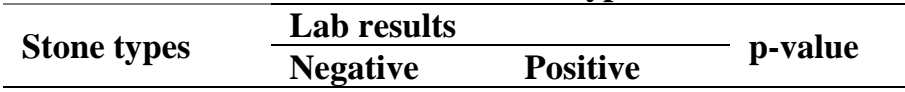

This publication is licensed under Creative Commons Attribution CC BY

http://dx.doi.org/10.29322/IJSRP.11.12.2021.p12039

\begin{tabular}{llll}
\hline $\begin{array}{l}\text { Cholesterol } \\
\text { stones }\end{array}$ & $11(36,7 \%)$ & $0(0 \%)$ & 0.002 \\
$\begin{array}{l}\text { Pigment stones } \\
\text { Mixed stones }\end{array}$ & $1(3,3 \%)$ & $9(30,7 \%)$ & \\
\hline Total & 12 & 18 & $5(16,7 \%)$ \\
\hline
\end{tabular}

In table 3 above, cholesterol stones with negative lab results were obtained as many as 11 people $(36.7 \%)$, and none of them had positive results. As for pigment stones, 1 person $(3.3 \%)$ negative results and 9 people $(30.7 \%)$ positive results, and for mixed stones with negative lab results 4 people $(13.3 \%)$ and positive lab results 5 people (! 6.7\%). From the test above, it was found that there was a relationship $(\mathrm{p}<0.05)$ between the type of stone and the lab results.

\section{DISCUSSION}

In this study several results were found, namely stones occur mostly at the age of over 40 years, occur more in women, cholesterol stones are the most stones, on examination of bacteria more are negative, most samples do not find germs, in samples with germs found Klebsiella pneumoniae the most and Enterococcus faecalis the least, the number of cholesterol and pigment stones is the same in proportion for the age group under 40 years, and cholesterol stones and mixed stones will be more at the age above 40 years, in men the most stones are cholesterol stones and Pigment stones are most commonly found in the female sex.

The results of negative bacteria are more in the age group under 40 years, and above 40 years are the same as in the lab results, female patients generally have positive stones and males are more dominantly negative, and The type of stone has a relationship with the laboratory results of the microorganism. Based on this study, the most age occurred at the age above 40 years. This is in accordance with previous studies where most occur at the age of over 50 years (Hohlacheva, Sergeeva and Vahrushev, 2016).

Based on this study, it was found that stones were most common in women, this is in accordance with previous studies (Kuy et al., 2013; Ahmad et al., 2015). Based on this study, it was found that stones containing cholesterol were the most common stones. Based on this research, the results of the microbiology lab are more negative than positive. This is in accordance with previous studies that only $25 \%$ of stone samples had positive results (Kuy et al., 2013; Ahmad et al., 2015).

Based on this study, most of the samples did not find germs, the samples with bacteria found the most Klebsiella pneumoniae and Enterococcus faecalis the least. This seems to be different from the bacteria profile that should be dominated by bacteria that are abundant in the intestinal tract such as the genus Clostridium, Bifidobacterium, Peptostreptococcus, Bacteroides, Eubacterium, and Escherichia coli species (Grigor'eva and Romanova, 2020). Researchers suspect this is because food hygiene standards in Indonesia are still not good, thus allowing the class of bacteria that infects the food tract to be found in gastrointestinal diseases.

Based on this research, the number of cholesterol and pigment stones is the same for the age group under 40 years and cholesterol stones and mixed stones will be more at the age above 40 years, this is in accordance with previous research 
(Hohlacheva, Sergeeva and Vahrushev, 2016). Based on this study in men, the most stones were pigment stones and cholesterol stones were most commonly found in the female sex. This is in accordance with previous research which found more cases of cholesterol stones in female patients (Hohlacheva, Sergeeva and Vahrushev, 2016). This is thought to be due to the high levels of estrogen in women (Zhang et al., 2019).

Based on this study, the results of negative germs were more in the age group under 40 years, and above 40 years the same number in the lab results. In previous research, it was found that there was no difference in age above or below 65 years (Zhang et al., 2019). This is thought to be due to differences in dietary patterns that occur here and in China. Then there is a suspicion that there is a relationship between oral hygiene that can increase the likelihood of infection in gallstones (Grigor'eva and Romanova, 2020).

\section{CONCLUSION}

In this study, several results were found, namely stones occur mostly at the age of over 40 years, occur more in women, cholesterol stones are the most common stones, and on examination of bacteria more are negative. In this study, the proportion of cholesterol and pigment stones was the same for the age group under 40 years, and cholesterol stones and mixed stones were more common in those aged over 40 years.

In this study, the most common stones were cholesterol stones and pigment stones were found in the female sex, the results of negative germs were more in the age group under 40 years, and above 40 years were the same as in the lab results. In this study, female patients generally had positive stones and males were more dominantly negative, and the type of stone had a relationship with the microorganism lab results.

\section{REFERENCES}

Al-Saad, M. H., Alawadh, A. H. and Al-Bagshi, A. H. (2018) 'Surgical Management of Cholelithiasis', The Egyptian Journal of Hospital Medicine, 70(8), pp. 1416-1420. doi: 10.12816/0044658.

Bistgani, M. M. and Imani, R. (2013) 'Bacteria isolated from patients with cholelithiasis and their antibacterial susceptibility pattern', Iranian Red Crescent Medical Journal, 15(8), pp. 759-761. doi: 10.5812/ircmj.3883.

Blumigart, L. H. (2017) 'Stone in the Common Bile Duct-Clinical Feature and Open Surgical Approaches and Tehniques In Surgery of the Liver,Biliary Tract,and Panceas. Saunders. Philadelphia. 4 (1): 4528-547. Gallstone
Analysis', The Indonesian Journal Gastrenterologi/Hepatologi and Digestive Endoscopy, I(4), pp. 54-60.

Brunetti, J. C. (2018) Imaging in Gallstones (Cholelithiasis): Practice Essentials, Radiography, Computed Tomography, Medscape.

Cariati, A. (2014) 'Gallstone Classification in Western Countries', (May). doi 10.1007/s12262-013-0847-y.

Carroll, K. C. and Hobden, J. A. (2016) Jawetz, Melnick \& Adelberg's Medical Microbiology 27th Edition. 27th Editi. Edited by K. C. Carroll et al. New York: McGraw-Hill Education.

Chang, Y. R. et al. (2013) 'Changes in Demographic Features of Gallstone Disease : 30 Years of Surgically Treated Patients', 7(6), pp. 719-724.

Ciaula, A. Di et al. (2021) 'An update on the pathogenesis of cholesterol gallstone disease', 34(2), pp. 71-80. doi: 10.1097/MOG.0000000000000423.An.

Grigor'eva, I. N. and Romanova, T. I. (2020) 'Gallstone disease and microbiome', Microorganisms, 8(6). doi: 10.3390/microorganisms 8060835 .

Gyedu, A. et al. (2015) 'Prevalence of cholelithiasis among persons undergoing abdominal ultrasound at the Komfo Anokye Teaching Hospital , Kumasi , Ghana .', 15(1), pp. 247-250.

Han, J. et al. (2021) 'Biliary Microbiota in Choledocholithiasis and Correlation With Duodenal Microbiota', 11(April), pp. 1-11. doi 10.3389/fcimb.2021.625589.

Hohlacheva, N. A., Sergeeva, N. N. and Vahrushev, Y. M. (2016) 'Age and Gender Peculiarities of Development of Gallstone Disease', Archive of internal medicine, 6(1), pp. 34-39. doi: 10.20514/2226-6704-2016-6-1-34-39.

Karnadiharja, W. (1997) Gastroenterologi Hepatologi. Edited by H. Sulaiman. Jakarta: CV. Sagung Seto.

Kereh, D. S. et al. (2015) 'Hubungan Antara Jenis Batu dan Perubahan Mukosa Kandung Empedu pada Pasien Batu Kandung Empedu', Jurnal Biomedik (Jbm), 7(3), pp. 41-47. doi: 10.35790/jbm.7.3.2015.10441.

Kuy, Sreyram et al. (2013) 'Gender based differences in management and outcomes of cholecystitis', American Journal of Surgery, 206(5), pp. 641646. doi: 10.1016/j.amjsurg.2013.07.011.

Lambou-Gianoukos, S. and Heller, S. J. (2008) Surgical Clinics of North America. Volume 88. Edited by C. Bewick. Philadelphia: Elsevier.

\section{AUTHORS}

First Author - Rizki Fadhil Nasution, Department of Surgery, Faculty of Medicine, Universitas Sumatera Utara.

Second Author - Asrul, Department of Surgery, Faculty of Medicine, Universitas Sumatera Utara.

Third Author - Adi Muradi Muhar, Department of Surgery, Faculty of Medicine, Universitas Sumatera Utara.

Fourth Author - Putri Chairani Eyanoer, Department of Surgery, Faculty of Medicine, Universitas Sumatera Utara

Correspondence Author - Rizki Fadhil Nasution, Department of Surgery, Faculty of Medicine, Universitas Sumatera Utara, email: dr.fadhilnst@gmail.com 